\title{
The Social Status of Indian Women of Different Periods in the Patriarchal Society
}

Dr. Ramesh H. Patil, Associate Professor, Dept. of Sociology, Smt. Kusumtai

Rajarambapu Patil Kanya Mahavidyalaya Islampur Dist- Sangli (MS)

Electronic version

URL: http://www.researchambition.com

DOI: https://doi.org/10.53724/ambition/v5n4.06

ISSN: 2456-0146

Vol. 5, Issue-IV, February 2021

Page No. 23-31

Publisher

Welfare Universe

email: publish2017@gmail.com

OResearch Ambition: An International Multidisciplinary e-Journal 2021. This Open Access article is published under a Creative Commons Attribution Non-Commercial 4.0 International License https://creativecommons.org/licenses/by-nc/4.0/, which permits non-commercial reuse, distribution, and reproduction in any medium, provided the original work is properly cited. For citation use the DOI. For commercial re-use, please contact editor email:- publish2017@gmail.com By accessing the work you hereby accept the Terms. Non-commercial uses of the work are permitted without any further permission from Research Ambition: An International Multidisciplinary eJournal provided the work is properly attributed. 


\title{
The Social Status of Indian Women of Different Periods in the Patriarchal Society
}

${ }^{*}$ Dr. Ramesh H. Patil

\begin{abstract}
This study seeks to study the social status of women in India from ancient times to the present day. It mainly studies the social status of women in each era. The findings of this study show that in every age, the status of women has always been secondary to that of men and in patriarchal societies. At the same time, the social, economic, educational, marital, cultural and religious status of women in our society is inferior to that of men. Even today, in the 21st century Indian patriarchal society, women do not have the same status as men. The findings of this study attempt to analyze the social status of women in all areas of a patriarchal society. In Indian society, the role of women is secondary in all aspects of society, such as family, religion, law and media. Everything like reproduction, labor force, sexuality, means of production are under the control of culture. This is why in all these cases woman is left behind in the social position as a man. Considering the social relations between men and women at different levels of social life, it is seen that women do not get equal status with men in all aspects of social life like family, religion, caste and culture. She thinks of men as slaves, possessions, and possessions. In social life, women have been deprived of political, religious, cultural and family rights. "Chool and Mool”, "Muki Bichari- Kunihi Haka" is the attitude towards women which is found to be sexually motivated.
\end{abstract}

Keywords: matriarchal, patrimony, gratification, worshiped, personality, revolutionary.

\section{Introduction}

Today, in the 21st century, the attitude of men who call themselves modern is exceptionally modern in the case of women. The majority of men look at women from a traditional point of view. His attitude towards women is at the root of many of his problems. Not only that, but in the masculine society, men are really superior to us, we are inferior, so we feel like we need the protection of men. Therefore, this gender based attitude created in the society is causing problems in the lives of women. Women and men are members of society and society looks at them from different perspectives without looking at them equally. It also treats them differently without treating them the same way. That is, society discriminates between men and women. E.g. Women should behave like this, men should behave like this, and society

\footnotetext{
${ }^{*}$ Associate Professor, Dept. of Sociology, Smt. Kusumtai Rajarambapu Patil Kanya Mahavidyalaya Islampur DistSangli (MS)
} 
discriminates in many aspects like women's dress, women's standard of living, men's standard of living. The term gender is used to denote the differences between men and women in society.

Biological and physical characteristics of men and women are different. Society also determines some of the different characteristics of men and women at the social and cultural level. It is mainly about women being cowardly, men being brave, women being weak, men being strong, women being tolerant, men being aggressive, women being emotional, men being capable, women being submissive, men being dominant and ambitious. Societies are not created by nature. This gives rise to the term gender. Society expects men and women to behave differently. In general, the society has stated certain things about what a woman should do, how she should behave, mainly housework, cooking, child rearing are related to women, while men are expected to do hard work outside the family.

\section{Objectives of the study:}

1) To study the social status of women.

2) To study the secondary position of women as compared to men

\section{Research method:}

The presented research essay is based on secondary tools. All the data required for this study has been obtained through various book, internet and newspapers. The purpose of this study the social status of women in India, so the study has been completed by collecting the relevant data.

\section{Discussion:}

\section{Ancient Period:}

It is possible to review the status of women in the three periods of ancient times, namely, the Matriarchy period, the Vedic period, and the post-Vedic period.

\section{Matriarchy period}

In ancient times, the attitude towards women was similar to that of women. Because men did not know that men are involved in disaster creation .Everyone felt that there is a potential for innovation between earth and women and that there must be some divine basis for it. Apart from this, women also invented agriculture. Due to this very important achievement of women, the nomadic society became stable to some extent. So the problem of water was solved, the society became stable and only after that the matriarchal system came into existence in the society.

In a matriarchal society, men and women were equal. Women were at the forefront of martial arts, Ayurveda and statistical philosophy. Anarya culture was feminist. And Aryan culture was patriarchal. References to Shurpanakha, Tratika and other non-Aryan women Ganadhipatis appear in the Ramayana. 
These women were the head of the family. He was treated with respect in the society and family. Anarya women had freedom of decision. ${ }^{1}$

They had a system of self-determination. In the primitive Gana society, women not only did the work of building the framework of Yajna, laying bricks, etc., but also had the right to distribute the role of Gana. What women have made important for human life is the invention of geometry. Fortunately, the status of women remained high in the matriarchal society. ${ }^{2}$ later in agriculture technology; traditional farming ideas were overtaken by the use of plows and livestock for agriculture. At the same time, the place of man in childbirth became clear. As a result, the idea of feminine mahatma came to an end and motherhood was replaced by patriarchal culture in the society. ${ }^{3}$

\section{Vedic period}

The Aryans arrived in India between 3,000 BC and 2500 BC. The Aryans defeated the matriarchal nonAryan culture that existed in Indian society. And established discrimination in the Indian system by establishing caste. In the Vedic period, women had the right to education. Therefore Brahmavad in iremained, unmarried throughout their lives and practiced enlightenment. However, there were no oppressive practices such as child marriage and sati till the time of marriage, but women did not have the right to property. There are two streams of thought regarding women in India. One stream considers gender equality, while the other stream considers women only inferior. It is called 'Apastambhthat' when a woman is walking down the street, everyone should wait for her. ${ }^{4}$ this shows his liberal outlook, and the 'Pre-Manusmriti' period is influenced by the cultural matriarchal family system of the 'Anaryas, which gives women a degree of equal status with men. According to 'Prof. Ram Ahuja', during this period, women were not earning money but were seen working in the field of agriculture. The woman used to get her share of patrimony. The mother's wealth was shared equally among the sons and daughters. ${ }^{5}$ there was constant conflict between Arya and Anarya. Therefore, women were responsible for the home. Women were involved in housework, textile making, food preparation, hunting, fruit picking and other such production processes. Because in some 'Upanishads', there are stories of 'Gargi and Maitreyi'. It is said that she was a Vidushi woman of the Vedic period. The greatness of that time is also mentioned. So there is exceptional reality.

In this context too, "Dr. A.H.Salunkhe" says, but at the same time a strange sadness remains in the mind and that is that the picture of Gargi and Maitreyi is not a representative picture of the Indian women of that time but an exceptional reality. ${ }^{6}$

\footnotetext{
${ }_{1}^{1}$ Ahire, P., Samajshastriy Pariprekshyatun Streech Aatmakathane, Kailash Publication, Aurangabad, (2011) Pg-24.

${ }^{2}$ Khadase, S \& Khadase S, Etihasik Pariprekshyatun Striya, Shubham Publication Pune. (2010) Pg-18.

${ }^{3}$ Khadase,S \& Khadase S,Etihasik Pariprekshyatun Striya, Shubham Publication Pune. (2010) Pg-19.

${ }^{4}$ Ahuja, R (1995), Bhartiy Samajik Vyavashta, Ravat Publication, Jaipur. Pg-75.

${ }^{5}$ Ibid.

${ }^{6}$ Salunkhe, A. (1989), Hindu Sanskruti ani Stiree, Lokvagmay Gruh, Mumbai. Pg-34.
} 


\section{Post Vedic period}

The period from $1500 \mathrm{BC}$ to $500 \mathrm{AD}$ is known as the North Vedic period. During this period Ramayana and Mahabharata were created as epics. This period was a period of transition towards the status of women. In the post-Vedic period, the status of women began to decline. 'Manuvachan clarifies', the status of women in the society, in which they should not live in the country where they are leading. ${ }^{7}$ The defeat of the Aryans and Anaryas during this period helped them to stabilize their lives. With no Aryan opponents left, women's economic and political participation in such a stable life diminished. As a result, the status and position of women began to decline. The level of female education in the Vedic period became very narrow in the post-Vedic period. The participation of women in public life became very narrow. Due to the defeat of the Aryans in the struggle of the Aryans, the non- Aryans joined the service of the Aryans just like the non-Aryans. As a result, marriages between Aryan men and nonAryan women also began to take place.

Dr. 'Aaltekar' says, that; Aryan men established unnatural marriages with non-Aryan women, but Aryan theologians opposed the participation of non-Aryan women in religious activities. ${ }^{8}$ Therefore, women were barred from entering the religious life. Due to the strong caste system, child marriage was sanctioned due to fear of cross-breeding. Many restrictions were imposed on women during this period to keep the patriarchy intact. The Arya Samaj tried to destroy the matriarchal system with the help of many cruel practices. In this regard, "Dr. Gadgil" says that the patriarchal Vedic Arya Samaj tried to destroy the matriarchal system with the many help of much cruel practices. ${ }^{9}$ Child marriage, polygamy, inhuman treatment of widows and the practice of sati are all enlightening in this regard. Men are superior to women. On These tricks were perpetuated by the thinkers who grew up in India.

During this period, scriptures were composed to add religion to the inferior and secondary status of women. 'Manusmriti' was also composed during this period. Due to the addition of religion to the secondary status of women, the status of women was degraded. Overall, the system of women was degraded due to the influence of 'Manusmriti' and other similar scriptures. The age of marriage of women decreased. Child marriage system came into existence. She was expected to give birth to male offspring. And the child was determined as the field of work.

Therefore, the woman became ignorant, childish, and ignorant of religious practices, only a means of procreation and sexual gratification. Different rules were made about the character of men and women. Marriage became mandatory for her. Some of the ladies of kings and palaces enjoyed exceptional freedom. Epics, Puranas and other scriptures were considered ideal for 'Manusmriti'. This means that

\footnotetext{
${ }^{7}$ Ibid.

${ }^{8}$ Kondekar, A., Samajshatra, Anirudha Publising house, Pune, (1999) Pg-150.

${ }^{9}$ Gadgil, S., Lokayat, Lokvagmay Gruh, Mumbai.(2000) Pg-71.
} 
the condition of women in this period was the most difficult. Throughout the Puranic period, the status of women was deplorable due to Brahmin culture, rigidity of caste system, joint family, lack of female education, entry of non- Aryan woman as wife in Arya family and invasion by foreigners. ${ }^{10}$

Medieval period:

Generally, the period from 1200 to 1818 AD is considered as the medieval period. During this period, Indian life was a life dominated by inequality, injustice, ignorance and based on scriptures. Epics based on scriptures were the basis of society. Ramayana and Mahabharata are all full of such ideals. For example, in the Mahabharata, if the son of a Brahmin is a Brahmin, then if his mother is a Kshatriya and a Vaishya, it does not matter. ${ }^{11}$ Due to the transformation of caste system into caste system in the medieval period, this period of women's life is considered to be a dark period. The biggest victims of this caste system were women. Because women have a great responsibility to maintain the purity of the caste. For this, many restrictions were imposed on women. For this, women's right to education was taken away and women were enslaved in intellectual slavery. By associating the chastity of woman with religion, God-religion, vrat-vaikalya was engaged. The practice of child marriage came into existence so that a girl should not have inter-caste marriage. Widow Remarriage was banned so that widows should not have interracial marriages. At the same time, the practice of sati came into existence. Women were glorified and imprisoned by things like ideal mothers, ideal wives.

Islamic rule over India began in the medieval period. Therefore, the interaction between Hindus and Muslims influenced the tradition. Due to the different cultures between Islam and Hinduism, efforts were made to protect Hinduism and women from Islam. This resulted in the already degraded status of the woman and the status of the woman who was already inferior became even more secondary. ${ }^{12}$ As a result, Hindu women were confined within four walls. The condition of Muslim women was also very dire. She was not given any rights; she had to live her life under a burkha. As a result, their quality of life was extremely poor.

\section{Modern period:}

India's history to this day is dominated by patriarchal systems. Today's 21 st century is no exception. That is why the social, economic, political, cultural and educational status of women has been degraded even in modern times. According to Mr. Bhide Patil, the missionaries work helped to create a generation to social reformers in India and Maharashtra. ${ }^{13}$ Apart from a few things in the history of India from the Matriarchal period, during the British period, mainly Raja Ram Mohan Roy, Mahatma Phule did a lot of work on the question of women in the nineteenth century. Even if their work is not enough,

\footnotetext{
${ }^{10}$ Ahire, P., Samajshastriy Pariprekshyatun Streech Aatmakathane, Kailash Publication, Aurangabad, (2011) Pg-30.

${ }^{11}$ Garge, S., (ETD), Bhartiy Samajvidnyan Kosh, Bhag-5, Samaj Vidnyan Mandal, Pune, (1991) Pg-24.

${ }_{12}^{12}$ Ahire, P., Samajshastriy Pariprekshyatun Streech Aatmakathane, Kailash Publication, Aurangabad, (2011) Pg-32.

${ }^{13}$ Bhide, L., Maharashtratil Samajsudharnecha Etihas, Fadake Prakashan, Kolhapur, (1991) Pg-44.
} 
change seems to have begun. The modern epoch of women's development can be divided into two periods, one pre-independence and the other post-independence. The role of women in society can be understood in both these periods.

\section{Pre-independence period}

In Indian society, women were worshiped as mothers and gods; while on the other hand, women were treated as secondary. In the nineteenth century, women had a secondary place in society and at home. No scope was given to her activism. From the beginning of the British rule in India in the early nineteenth century, a new system of colonialism and capitalism came to the Indians. During this period, the British tried to prove their moral supremacy by assuming that there was an oppressed group called Indian women. Indian social reformer Raja ram Mohan Roy first enacted the Prohibition of Sati Act in 1829 with the help of Lord Betting. Recognizing that the main reason for the backwardness of Indians was the confinement of women, Mahatma Jyotiba Phule started the first school for girls in Pune in 1848. This highly revolutionary decision began to change the lives of Indian women. ${ }^{14}$ Widow Remarriage was later enacted in 1856 but was not adopted by the then society. Later, Mahatma Phule set up a child murder prevention home. Mahatma Phule and Savitribai Phule were of the view that widows, abandoned, destitute women in a society victimized by male injustice should not end their lives, and they should give birth to their children in a child prevention home and take the child home if they want or with child murder prevention.

Initially, women were educated in the British education system. Pandita Ramabai and Tarabai Shinde shared their thoughts on the truth-seeking rebellious legacy. A small number of women participated in the freedom struggle. Also, the participation of women in the political, social, economic and educational spheres began to increase. But in the male-dominated system, the status of women has not changed much.

\section{Post-independence period}

Democracy was adopted after independence. India adopted an independent constitution. The Constitution gave women equal status with men. Dr. Babasaheb Ambedkar was elected as the Law Minister in the Indian Legislative Council. He introduced the Hindu Code Bill in Parliament to achieve equality for women, but it was not accepted by the male-dominated leaders of the time. For this, Dr. Babasaheb Ambedkar had the courage to resign from his post. After that, many women's liberation organizations were formed to give scope to women's intellect, deeds and work force. These organizations strive for the holistic development of women by creating awareness, self-esteem and self-

\footnotetext{
${ }^{14}$ Dhondage, A,Stree- Purush, Diparaj Prakashan,Pune, (2003) Pg-134.
} 
respect. ${ }^{15}$ Today, women have proved their mettle in the fields of education, literature, art, politics and sociology.

The 20th and 21st centuries are very important for Indian society .This period has literally brought about many radical changes in the lives of Indian women. During this period, the personality of the woman changed, the social, cultural and familial existence of the woman became meaningful. Society's attitude towards women is being formed anew. The main thing is that as a woman realizes her selfesteem, a new way of looking at her and many things in life is being created. The ability to make decisions about your personality development has been acquired in modern times. As a result, one's own identity is evolving as one is able to recognize many latent, suppressed abilities and experiences in one's own personality.

Today, women have made their debut in various fields like literature, music, art, politics, administration, drama-film, education. Today no area is excluded from woman. We have tried to ensure our existence by proving our ability to work in various fields of society. Today, the social and cultural environment around women is changing. In every opportunity that arises from it, women have proved their existence.

Nevertheless, when considering the social status of women in the society and the gender factor in the social stratification, the gender status is considered. From the British era, the status of Indian women began to improve. In the post-independence period, conscious efforts were made through various progressive laws, various projects, and opportunities for women in various fields, etc. Women also tried to raise their status by developing their abilities. But does a patriarchal society really treat women as equal to men? Is it given equal status? It is important to look at this here. During this period, women have tried to prove their existence in education, jobs, business, politics, and social activity in the postindependence period.

\section{Conclusion}

In modern times, the place of women in society and the problems of women are being discussed on a large scale globally. In India, too, the issue of women is being widely considered. Women's study centers have been set up at various colleges, universities, NGOs, etc. to study the place of women in society, their issues and problems.

Research is being done on women's issues. Feminist thinkers are drawing the attention of everyone in the society to the question of women. But in the twenty-first century, the tendency to write less than men seems to have persisted, when it comes to intelligence, physical ability, the threat of creativity, etc. The majority of societies in the world are patriarchal. In a patriarchal society, the status of women is considered secondary, in fact it is. Considering the social roles of men, the role of men is considered

${ }^{15}$ Ahire, P., Samajshastriy Pariprekshyatun Streech Aatmakathane, Kailash Publication, Aurangabad, (2011) Pg-22. 
superior while the role of women is considered secondary. Also, the social status of the work done by women is considered inferior while the quality of work done by men is considered superior. In a patriarchal society, men have rights in all spheres of life while women are always deprived of rights. It is viewed from a masculine point of view. From that point of view, social, political, cultural, economic, religious, educational, historical, At many levels of justice, women are being treated unfairly and oppressed.

Although men and women are essential for reproduction and social development, the birth of a woman at the social level is not welcomed. On the whole, women are viewed with the feeling that they are physically, mentally and ideologically weak. Gender inequality in the context of marriage is widespread. In traditional society, marriage was performed at an early age. The marriage of a girl child is decided by the parents today. In the traditional society, only men had the right to divorce. Today, even though the law gives women the right to divorce, it is not used by all women. Today, many women are living a life of abandonment. In Indian society, women are oppressed in the name of culture and religion. In the book; 'Manusmriti' woman is called inanimate. Inanimate means a woman who has no limbs, that is, one who has no control over her own organs, a woman who has the senses of her husband is called inanimate. It means that a woman should be completely dependent on her husband's senses, intellect and way of thinking. We find that women are given a secondary place in all levels, be it religious, social, political, economic. Religious and cultural elements impose various restrictions on each level of living. The cultural systems of all societies are patriarchal. Therefore, men dominate in the production and presentation of cultural elements like knowledge, art, song, music, dance etc. Today, stories, novels, movies, television series, and traditional entertainment are all designed with men at the center. In most of the plays and films, the role of men is secondary to that of women. Even in clothes, ornaments, religious life, cultural matters, women are given a secondary place. Gender is part of the socio-cultural structure. In a patriarchal society, the superiority of men and the inferiority of women have been increasing since time immemorial. This is an injustice done to women from the point of view of gender. Men are getting family property rights, inheritance rights. After marriage, daughters have to leave their fathers house and move to their husband's house. Men control all the transactions that take place in the family. Even though women are involved in the decision making process of the family, it is not always a decision based on a woman's opinion. In a traditional family, women did not have the right to property, but today the law allows a girl to give up her father's property after her marriage. In a patriarchal family system, the birth of a son is more welcome than the birth of a daughter. A girl is a curse, a responsibility, a foreigner's mentality. Today, female feticide is a problem. As a result, many states in India today have a lower proportion of women than men. 
In Indian society, the role of women is secondary in all aspects of society, such as family, religion, law and media. Everything like reproduction, labor force, sexuality, means of production are under the control of culture. This is why in all these cases woman is left behind in the social position as a man. In Indian society, women have been kept out of politics since time immemorial, with few exceptions. Today, in most of the countries, there is a democratic political system where women have the same opportunity to participate in the political process as men, but even in a democratic system, women's political participation is less than that of men. Today, even in a developed country like the United States, a woman does not have the opportunity to become the head of state. In a country like India, women are not represented by political parties. In India, the bill to give 33 per cent reserved seats to women could not be passed in the legislature. Therefore, the proportion of women representatives in the Central and State Legislative Boards is low. With 33 per cent reservation in the panchayat system, their participation in politics is increasing. However, in local politics, only men are seen in charge of women. Women are not given any form of political leadership.

In the post-independence era, women are being provided education, jobs and business opportunities with the idea that if they become educationally and financially self-sufficient, it will truly enhance their social status. Women are working alongside men in job- business, she has proved her existence. Yet the question of equal pay, the mental-physical abuse that occurs, and the attitude of discrimination is evident. In the economic sphere too, there is discrimination between men and women in many areas such as division of labor, property rights. Indian society has a long history. Every society in India is influenced by the patriarchal system. In ancient times, with few exceptions, the status of women in Indian society has always been inferior. This is an injustice to women.

Today, in the 21 st century, the attitude of men who call themselves modern is exceptionally modern in the case of women. The majority of men look at women from a traditional point of view. His attitude towards women is at the root of many of his problems. Not only that, but in the masculine society, men are really superior to us, we are inferior, so we feel like we need men's protection. So the attitudes of the society are causing problems in the lives of women. In every society, roughly half of the population is made up of men and women. Women are as much a part of society as men, so any form of society can be evaluated only on the basis of social status, status and role of women. In every period of the history of the world, human beings have been treated as secondary human beings. Today's situation is no different. In a society, woman has always been given secondary importance at the religious, social, economic and cultural levels.

$* * * * * * * * * * * * * * * * * * * * * * *$ 